20. Opanasyuk, O. P. (2018). Intentionality in the Area of Culture: Art Criticism, culturological and philosophical aspects. The publication 2. Kyiv: Aura Buks [in Ukrainian].

21. Salm, A. A. (2007). Intentional dynamics in the Sonatas for fortepiano of Valentina Silvestrova. Herald of the Russian academy of music of the name of the Gnesinyih, 2, 135-143 [in Russian].

22. Shpengler, O. (1993). The decline of Europe. Descriptions of the morphology of the world history. 1. Gestalt and the reality. Moscow: Myisl [in Russian].

Стаття надійшла до редакції 18.11.2019 р. Прийнято до публікації 17.12.2019 p.

УДК 766:7.05

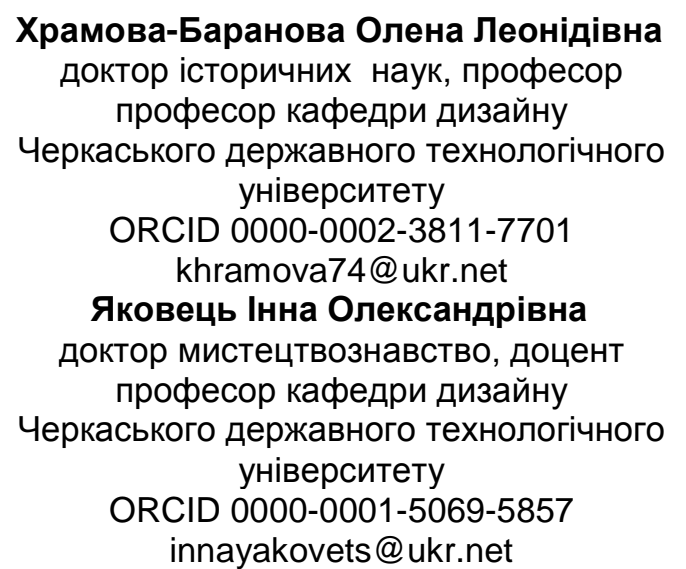

\title{
ВПЛИВ ГРАФІЧНИХ ТЕХНІК НА РОЗВИТОК ОБРАЗОТВОРЧОГО МИСТЕЦТВА І ДИЗАЙНУ В УКРАЇНІ
}

\begin{abstract}
Мета роботи. Виконати мистецтвознавчий аналіз декількох графрічних технік і їх впливу на розвиток образотворчого мистецтва і дизайну в Україні в XX ст. з позиції репрезентації і популяризації української культури, що дасть можливість показати перспективи графічних технік в мистецтві. Методологія дослідження полягає у застосуванні конкретно-історичного методу для аналізу впливу графічних технік і здобутків митців в популяризації українського мистецтва, а також використанні методу порівняльного аналізу і історико-культурного підходу, що сприятиме виявленню основних тенденцій розвитку графрічних технік в творчості українських митців в світовому контексті. Наукова новизна полягає у спробі осмислення і виявлення основних тенденцій розвитку графрічних технік в репрезентації української культури і творчості українських митців в XX ст., що зумовлено історичними, соціальними, культурними процесами. Висновки. Аналіз сутності і репрезентації графрічних технік в творчості українських митців вказує на взаємозалежність давньої культурної спадщини і досягнень початку XX століття, що уможливлює вдосконалення графічних технік і має вплинути на розвиток образотворчого мистецтва і дизайну в Україні.
\end{abstract}

Ключові слова: графічні техніки, естамп, образотворче мистецтво, дизайн.

Храмова-Баранова Елена Леонидовна, доктор исторических наук., профрессор, профессор кафредры дизайна Черкасского государственного технологического университета; Яковец Инна Александровна, доктор искусствовоедения, доцент, профрессор кафедры дизайна Черкасского государственного технологического университета

Влияние графических техник на развитие изобразительного искусства и дизайна в Украине

Цель работы. Выполнить искусствоведческий анализ некоторых графических техник и их влияния на развитие изобразительного искусства и дизайна в Украине в XX в. с позиции репрезентации и популяризации украинской культуры, что позволит показать перспективы графических техник в искусстве. Методология исследования заключается в применении конкретно-исторического метода для анализа влияния графических техник и достижений художников в популяризации украинского искусства, а также использовании метода сравнительного анализа и историко-культурного подхода, что будет способствовать выявлению основных тенденций развития графрических техник в творчестве украинских художников в мировом контексте. Научная новизна заключается в попытке выявления основных тенденций развития графических техник в репрезентации украинской культуры и творчества украинских художников в XX в., что обусловлено историческими, социальными, культурными процессами. Выводы. Анализ сущности и репрезентации графических техник в творчестве украинских художников указывает на взаимозависимость давнего культурного наследия и достижений начала XX века, что помогает развитию графических техник и должно повлиять на изобразительное искусство и дизайн в Украине.

Ключевые слова: графические техники, эстамп, изобразительное искусство, дизайн.

() Храмова-Баранова О. Л., 2020

() Яковець І. О., 2020 
Khramova-Baranova Elena, doctor of sciences, professor, Professor of the Department of Design, Cherkasy State Technological; Yakovets Inna, doctor of sciences, Associate Professor, Professor of the Department of Design, Cherkasy State Technological University

The influence of graphic techniques on the development of visual art and design in Ukraine

The purpose of the article is to perform an art history analysis of some graphic techniques and their influence on the development of fine art and design in Ukraine in the twentieth century from the position of representation and popularization of Ukrainian culture, which will allow showing the prospects of graphic techniques in art. The methodology of the research is to use a concrete historical method to analyze the influence of graphic techniques and achievements in popularizing Ukrainian art, as well as using the method of comparative analysis and historical-cultural approach, which will help identify the main trends in the development of graphic techniques in the work of Ukrainian artists in the global context. The scientific novelty consists in an attempt to identify the main trends in the development of graphic techniques in the representation of Ukrainian culture and the work of Ukrainian artists in the 20th century, which is due to historical, social, and cultural processes. Conclusions. The development of graphic techniques is a significant contribution to the national fine arts and design, to the culture of Ukraine. It can be argued that graphic techniques have undergone significant changes since their inception. At the beginning of the XXI century, their technology becomes more complex and the texture of the print and the color solution becomes more complicated. Today, abstract, futuristic forms that are most characteristic of improvisational art are used, and contemporary artists continue to search for new tools and techniques for enriching graphic techniques. An analysis of the essence and representation of graphic techniques in the works of Ukrainian artists points to the interdependence of the long-standing cultural heritage and achievements of the early twentieth century, which helps the development of graphic techniques and should influence the visual arts and design in Ukraine.

Key words: graphic techniques, printmaking, art, design.

Актуальність теми дослідження. Питання впливу графічних технік як засобу графічної виразності на розвиток образотворчого мистецтва і дизайну $є$ одним з актуальних і його вирішення неможливе без вивчення найкращих зразків матеріальної та духовної культури. Необхідно дослідити застосування графічних технік з метою їх більш широкого використання в різних видах дизайну і образотворчого мистецтва, а також задля розкриття творчого потенціалу митця. Варто звернути увагу, що на сьогоднішній день мало досліджень з цієї проблематики, а поодинокі дослідження не повною мірою відображають вплив графрічних технік на розвиток образотворчого мистецтва. Актуальність роботи полягає в необхідності відродження та популяризації графічних технік, ефективному доборі засобів графічної виразності в мистецтві і дизайні. Дослідження дає можливість виявити основні концепції в репрезентації образотворчого мистецтва і дизайну графічними техніками.

У дослідженні застосовано конкретно-історичний метод для аналізу впливу графічних технік і здобутків митців в популяризації українського мистецтва, а також використання методу порівняльного аналізу і історико-культурного підходу, що сприятиме виявленню основних тенденцій розвитку графрічних технік в творчості українських митців в світовому контексті. Системний метод дає можливість комплексно дослідити складні системи, наприклад, образотворче мистецтво і дизайн в цілому, їх напрямки, значення особистості в розвитку графічних технік тощо. Цей метод передбачає вивчення кожного елемента системи графічних технік, його зв'язку з іншими елементами, а також встановлення оптимальних умов розвитку всієї системи.

Аналіз досліджень і публікацій. Досліджено історіографію проблематики і доведено, що над питаннями становлення і розвитку графічних технік в образотворчому мистецтві працювала невелика кількість науковців. Вагомий внесок в дослідження графічних технік зробили такі фрахівці як А.Лещинський, В.Фаворський, М.Мірошина, Н.Самойлова та ін. [1-5]. Вагомий внесок в дослідження ліногравюри зробили такі фахівці як В.Лопата, Г.Нарбут, Г.Якутович, Д.Якутович та інші. Однією 3 фундаментальних праць, яка описує техніку ліногравюри і її перспективи стала робота А.Лещинського «Основи графіки» (2003) [1]. В ній автор детально розповідає про види графіки, естамп, графічні техніки. В розділі книги мова йде, зокрема, про розвиток і становлення техніки ліногравюри, про різновиди технологій та прийоми виконання, про інструменти для створення відтисків, надаються ілюстрації робіт в цій техніці. Наприклад, у статті Г.Вовчок «Виховна функція ілюстрації дитячої книги» (2013) мистецтво дизайну книги для дітей розглянуто як один із методів виховання, який допомагає глибше і докладніше сприймати текст, в чому сприяють і графічні техніки [2]. В дисертації Г.Аксенова «Еволюція художньо-образної виразності в графічному дизайні в процесі розвитку поліграфічних засобів» (2008) досліджуються процеси і технології, пов'язані з друкарською підготовкою поліграфічної продукції. Це дослідження може бути використано в якості допомоги для тих, хто навчається за спеціальністю «Дизайн» спеціалізації «Графічний дизайн» і аспірантів, що займаються дослідженнями в галузі мистецтвознавства, графрічних технік і технології поліграфрічної продукції [3].

Мета дослідження полягає в ґрунтовному аналізі процесів становлення і розвитку графічних технік та використання їх в образотворчому мистецтві і дизайні, в необхідності аналізу творів митців, які працювали в означених графічних техніках. В дослідженні необхідно виконати мистецтвознавчий аналіз творчості декількох українських митців з позиції репрезентації образотворчого мистецтва і дизайну завдяки графічним технікам.

Виклад основного матеріалу дослідження. Графріка в якості основного образотворчого засобу використовує лінію, штрих і пляму, а композиція графічної форми залежить від графічної техніки і ма- 
теріалу. Мова графічного твору відзначається оперативністю і більш лаконічна у порівнянні 3 живописом. За призначенням і змістом графіка поділяється на: станкову, прикладну, газетну, книжкову, журнальну, плакатну, художньо-промислову. За способом виконання, графіку поділяють на: авторську (особливі графічні твори); естампну (різновиди художнього друку); масову поліграфічну продукцію. До оригінальних графічних творів відносять рисунки сангіною, вугіллям, олівцем, пастеллю та іншими матеріалами. До естампної графіки як художнього друку відносяться друковані форми з яких можливо отримувати декілька відбитків, а способи художнього друку класифікуються за створенням друкарської форми і особливостями друку [1]. Графрічні техніки застосовуються як засіб виразності в графічному дизайні як художньо-проектній діяльності, основним засобом якої є рисунок, а метою графічного дизайну $є$ візуалізація інформації для масового поширення за допомогою поліграфії, телебачення, комп'ютерних мереж тощо.

Одна з найдавніших графічних технік - рисунок пером і тушшю. Перо - інструмент для рисування, головним чином, тушшю або чорнилом, відоме у народів Сходу як «калам». Ще з давнини використовували пера пташині і очеретяні, а у кінці XVIII ст. почали використовувати металеві пера, які дають тонку і рівну лінію, штрих. Очеретяні і гусячі пера дають більш енергійний штрих, хоча можливості їх більш обмежені, ніж у металевого пера. Поршневі або кулькові ручки зручні для нанесення рівних ліній однакової щільності, але незважаючи на переваги поршневих ручок, найбільшу експресивність надають класичні технології, а саме: рисунок пером і очеретяною паличкою, що дозволяє проводити тонкі лінії і різкі чорні штрихи. Туш - матеріал для малювання пензлем або пером, виготовляється із сажі та клею. Наприклад, в цій графічній техніці працював англійський графік Обрі Вінсент Бьордслі. Характерною рисою картин О.Бьордслі $€$ відсутність зайвого, а саме: кожна деталь знаходиться на своєму місці. Митець, розташовуючи маси чорних і білих плям, провідну роль в композиції надавав рівновазі та контрасту. Насичені деталями, виконані однією лінією фрігури і предмети в творах О.Бьордслі - об'ємні і емоційно виразні. О.Бьордслі займався самовдосконаленням та самовихованням: перш ніж розпочати процес створення графічного твору, вивчав історію мистецтва, визначав найбільш вдале використання прийомів композиції, кольорового вирішення, що згодом застосовував у своїх творах. Ескізів митець не виконував, а першою визнаною роботою О.Бьордслі стали ілюстрації до книги англійського письменника XV ст. Т.Мелорі «Смерть Артура» (1893-1894), яка була створена за легендою про короля Артура. Зображення ілюстрацій побудовані на контрасті темного фону і світлих фрігур, промальованих лінією, а рухи фігур, декоративний рисунок рослин відрізняються напруженістю ліній. Рисунки О.Бьордслі в ілюстраціях до п'єси О.Уайльда «Соломея» (1894) виконано на світлому фоні, без зображення оточуючого простору, з мінімальною кількістю деталей. Більш пізні ілюстрації О.Бьордслі до журналу «Савой» насичені численними деталями, що передають характерні риси рококо, це і неймовірний пейзаж, і характерний настрій героїв [4].

Ліногравюра, офорт, ксилографія, літографія - фрорми сучасної графіки, які об'єднані загальним терміном «естамп». Естамп завдяки можливостям техніки розвинувся у самостійний вид мистецтва, це графічний твір, відтиснений з друкарської фрорми, обробленої способом друку на верстаті або вручну. Тираж отриманих відтисків коливається від двох до тисячі екземплярів і всі відтиски є оригіналами. Одна зі станкових технік ліногравюра - $\epsilon$ способом друку, заснованим на вирізанні рисунка на лінолеумі. Ця техніка з'явилася на межі XIX-XX ст., майже одночасно з винаходом лінолеуму і має певну схожість з технікою ксилографії (гравюра на дереві). Вперше її використали в 1905 р. художники німецької групи експресіоністів «Міст» для друку великих плакатів (плакати Ф.Блейля, 1906 р.). Матеріал лінолеум не тільки доступний, але і зручний для роботи, він легко розрізається і різець без зусиль проводить штрих будь-якої ширини. На лінолеумі можна виконувати гравюри великого розміру, використовувати їх в поліграфії від книжкової ілюстрації до плаката. Важлива риса ліногравюри - оперативність, оскільки на лінолеумі можна гравірувати набагато швидше, ніж на дереві, що дає більше можливостей для передачі безпосередності графічної мови [4].

Існує два основних види ліногравюри: чорно-біла та кольорова. Чорно-біла ліногравюра - це гравюра, виконана на основі чорної фарби у вигляді чорно-білого відбитка. Наприклад, І.Фаворський так писав про засоби виразності гравюри: «У гравюрі складається все з чорних, білих плям та штрихів, навіть сірого немає. Художник різними штрихами і співвідношенням чорного та білого прагне зобразити всі кольори, які бачить» [5]. Кольорова ліногравюра - більш складна техніка, оскільки для кожного кольору створюється окремий шар зі своїм вирізаним рисунком, потім шари поєднуються, шляхом послідовного накладання на основний аркуш. При створенні гравюри художники намагаються мінімальною кількістю фарб створити якомога більше колірних відтінків. Простий варіант кольорової ліногравюри виконуються шляхом нанесення декількох фрарб в певних місцях фрорми [2].

М.Шевердяев першим в XX ст. в Російській імперії став створювати гравюри на лінолеумі, його твори виставлялися в Парижі в 1907 році. Розвиток ліногравюри можна простежити і в роботах І.Павлова. Він став застосовувати техніку з 1909 року для оформлення обкладинок дитячих книг, створення ілюстрацій до них. Так ліногравюра замінила цинкографію і літографію. У 1914 р. був випущений календар «Цар-дзвін» на 1916 р. з 12 кольоровими ліногравюрами І.Павлова. Потім гравер став застосовувати техніку і для дизайну палітурок книг і нова техніка успішно застосовувалася як для створення книжкових ілюстрацій, так і для станкової гравюри. У своїй творчості її використовували: 
А.Дейнеко, Л.Ільїна, Б.Кустодієв, Д.Мітрохін, Г.Захаров, І.Голіцин, В.Фаворський, П.Староносов, А.Кравченко та інші. Піонером використання в Україні техніки кольорової гравюри вважається В.Фалілєєв. Художник працював в жанрі багатобарвної гравюри-пейзажу. Найвідоміші майстри ліногравюри в Україні - О.Кульчицька, О.Пащенко, В.Литвиненко, І.Селіванов, Г.Якутович та ін. В Україні в 1920-1930-х рр. у техніці ліногравюра працювали В.Замирайло, О.Кравченко та ін. Наприклад, В.Касьян створив цикл ліногравюр «Дніпрельстан» (1934), «Бригадир Г.Замковий», «Оленочка», «Т.Шевченко» (усі - 1960). О.Пащенко експонував кольорові ліногравюри краєвидів Києва та околиць (1937) та Дніпрогесу (1947). Українські художники-фронтовики (С.Єржиковський та ін.) працювали в газетах, виконуючи гравюри на дереві та лінолеумі. На початку 1960-х рр. при відділі у Харкові, Києві і Львові для розвитку графічних технік було створено експериментальні графічні майстерні з верстатами для відбитків, зокрема і плоского друку. У 1950-х рр. поширилася техніка кольорової ліногравюри, характерна для творчості львівських митців, а саме: Л.Левицького, Я.Музики, О.Шатківського. Завдяки ліногравюрі, О.Кульчицька наповнила твори більш гострим змістом («Герої», (1940-і рр.); «Війна», (1941); «У німецькому концтаборі», (1947)) та звернулася до побутового жанру (цикл «Культурне життя Львова», (1947)) [5].

У техніці естамп працювали й інші львівські художники. Наприклад, П.Обаль в своїх творах показав людину праці («Дроворуб. Минуле», (1950)), С.Лазеба створив баталістичні сцени («Б.Хмельницький під Жовтими Водами», (1954)). Історію та культуру Карпат зображено у творах 3.Кецала («До мужої хати», (1965)); «Світанок у Карпатах», (1966)), І.Остафійчука («Аркан», (1965)). У львівській графіці 1980-х рр. знову актуалізували техніку ліногравюра. У 1980-х р. знову почала розвиватися ліногравюра, в якій працювали П.Гуменюк, Д.Парута, М.Яців та інші. Наприклад, у 1960 р. С.Адамович створив цикл ліногравюр до повісті «Земля» О.Кобилянської, що стало початком у його творчості комплексного підходу до дизайну книги. Кольоровою ліногравюрою займався О.Івахненко, який виконав ілюстрації до лірики Т.Шевченка «Садок вишневий коло хати», (1982) та збірника «Поеми», (1984). Серія кольорової ліногравюри «Київ сучасний» (1987) стала вершиною творчості О.Фіщенка, а кольорова ліногравюра А.Смородіна «Гра», (2007) була відзначена дипломом Першого ступеня на IV Всеукраїнській виставці ім.Г.Якутовича у Києві (2008) [5].

Ліногравюра, як різновид граффічної техніки, зазнала значних змін в порівнянні з початком свого виникнення. В кінці XX ст. технологія ліногравюри стає складнішою, ускладнюється фактура відбитку і колірне рішення. Сьогодні станкова графіка вимагає живої безпосередньої участі творця з першої до останньої хвилини народження художнього твору. Отже, проаналізувавши техніку ліногравюри як засобу художньої виразності, зроблено висновок, що використання ліногравюри робить дизайн плакату, книги унікальним, неповторним, авторським. Ліногравюра допомагає створити новий емоційноестетичний образ, який не досягти комп'ютерною графікою.

Ще одна з графічних технік - монотипія, на відміну від всіх інших технік друкованої графріки, не потребує складного технічного обладнання. Монотипія $є$ найбільш рухливою технікою, що надає творам експресивності. Техніка монотипії полягає у нанесені фрарби на скляну поверхню з подальшим друком зображення на папері [6]. Іноді можна виконати і подальші відтиски, але вони будуть нижчої якості, наприклад, другий відтиск називається «привидом». Для відтиску можуть використовуватись трафарети, пензлі, акварельні фрарби, розчинники та інші засоби. Сам процес створення монотипії винайдено ще в 1640-х рр. італійцем Дж.Кастільоне (1609-1664), який виконав до 20-и монотипій [7]. Кольорову монотипію виконав англійський поет і художник У.Блейк (1757-1827), який використав монотипію у поєднанні з офортом. У Блейка монотипії є самостійними творами, а засоби і прийоми цієї техніки він використовував в своїх гравюрах та книжкових ілюстраціях. В XIX ст. методи створення кольорової монотипії захоплюють художників Європи, але потенціал цієї техніки глибше відчув в своїх творчих пошуках французький художник Е.Дега (1834-1917), який одним з перших оцінив її значимість і створив серію робіт в цій техніці. Е.Дега прагнув об'єднати монотипії з іншими техніками, що привело до нових відкриттів в цьому напряму. Коло художників, які працювали в цій техніці ширилося, наприклад, Каміль Піссарро (1830-1903) зробив кілька подібних робіт, Поль Гоген (1848-1903) використовував іншу техніку з підведенням контуру, яка пізніше була запозичена Паулем Клеє (1879-1940), О.Касіро використовував пластик, картон, листя, тканину, плавники риб як друковану основу [6].

3 XX ст. монотипія стала більш популярною, наприклад, Є.Круглікова відтворила техніку художнього відтиску. Є.Круглікова жила в Парижі, де працювала в техніках кольорового офорту, виконувала силуетні портрети, живопис, декорації та ескізи ляльок для театру маріонеток, займалася монотипією. В майстерні Є.Круглікової в Парижі зустрічалися талановиті митці, серед яких були М.Добров, М.Волошин, К.Костенко, В.Бєлкін та ін. [8]. В 1930-х рр. монотипією захоплювався А.Суворов, який в цій техніці виконав яскраві образи до повісті О.Толстого «Дитинство Микити». До цього періоду відносяться і монотипії А.Фонвізіна, які відрізняються своєю прозорістю і легкістю. М.Тарханов в цей час винайшов варіант монотипії, який назвав «акватипія», коли замість дошки використовував поверхню води, на якій тонким шаром розливалася олійна фрарба, а потім на неї накладався паперовий лист, який вбирав фрарбу [9]. Видатний український художник М.Глущенко (1901$1977)$ теж створював багато своїх пейзажів, натюрмортів, портретів саме в техніці монотипії. 
В кінці XX ст. митці, які працювали з монотипією, ставили перед собою завдання пошуку фактурних та колірних рішень. Яскравістю і нестримною фантазією відрізняються роботи М.РаубеГорчіліної, яка створювала складні орнаменти. В 1981 р. в місті Кохтла-Ярве (Естонія) Л.Т.Лівшиць (1930-1999) вперше організувала виставку фрактальних монотипій і назвала їх «стохатипіями». Завдяки хіміку В.М.Лівшиць і математику В.В.Скворцову в 2000 р. було означено фррактальну сутність монотипії і обґрунтовано поняття «фрактальної монотипії». Сьогодні монотипією займаються такі художники як А.Даур, В.Сова, О.Заяць, О.Щелчкова, Л.Лисянська, М.Красильнікова, М.Сотников та інші [7]. Монотипія в Україні, на жаль, не зайняла належного місця серед інших графічних технік, хоча вона $\epsilon$ однією з найцікавіших і доступних для широкого кола шанувальників образотворчого мистецтва. Каталог першого в Україні аукціону графіки (2011р.) представив твори, які розгортають широку панораму вітчизняного графічного мистецтва і графічних технік XX ст. Роботи засновників нової графічної школи в Україні М.Самокиша, О.Кульчицької подано поруч з творами відомих майстрів мистецтва українського авангарду, таких як О.Богомазова та В.Єрмилова.

Висновки і перспективи. Розвиток графічних технік - це вагомий внесок у національне образотворче мистецтво і дизайн, у культуру України. Можна стверджувати, що графічні техніки зазнали значних змін в порівнянні з часів їх становлення. На початку XXI століття складніше стає їх технології і більше ускладнюється фрактура відбитка та колірне рішення. Сьогодні використовуються абстрактні, футуристичні форми, найбільш властиві імпровізаційному мистецтву, а сучасні митці продовжують пошуки нових засобів і методів для збагачення графічних технік. На прикладі творчості Г.Якутовича, В.Касьяна, О.Кульчицької, О.Івахненко, М.Глущенко та ін. висвітлено процес цього становлення, а зібраний матеріал може бути використаний для розробки нових фрорм та пошуку нових засобів в процесі розвитку графічних технік і їх використання, що відобразиться в образотворчому мистецтві і дизайні. Аналіз сутності і репрезентації графрічних технік в творчості митців вказує на взаємозалежність давньої спадщини і досягнень XX століття, що уможливлює розробку концепцій подальшого використання графічних технік і вплине на розвиток культури в Україні.

\section{תimepamypa}

1. Лещинский А. А. Основы графики : учеб. пособие. Гродно : ГрГУ, 2003. 194 с.

2. Вовчок Г. М. Виховна функція ілюстрації дитячої книги. Видавничий дім «TM Меганом» : веб-сайт. URL :https://int-konf.org/ru/2013/suchasnist-nauka-chas-vzaemodiya-ta-vzaemovpliv-18-20-11-2013-r/610-vovchok-g-mvikhovna-funktsiya-ilyustratsiji-dityachoji-knigi (дата звернення : 11.07.2019).

3. Аксенов Г.П. Эволюция художественно-образной выразительности графического дизайна в процессе развития полиграфрических средств. Человек и наука : Диссертации по гуманитарным наукам : веб-сайт. URL http : //cheloveknauka.com/evolyutsiya-hudozhestvenno-obraznoy-vyrazitelnosti-graficheskogo-dizayna-v-protsesserazvitiya-poligraficheskih-sredstv\#ixzz5tNR6tE00 (дата звернення : 11.07.2019).

4. Мирошина М. Ю. Линогравюра: её виды в печатной графике. Молодой исследователь Дона, 2017. №3. C. $141-143$

5. Фаворский В. А. Об искусстве, о книге, о гравюре : монография. М : Издательство «Книга», 1986. 240

c.

6. Монотипія. Графіка. Вільна енциклопедія Вікіпедія : веб-сайт. URL https://uk.wikipedia.org/(Монотипія)_графріка (дата звернення : 11.07.2019).

7. Храмова-Баранова О.Л., Куколь С.Є. Становлення і розвиток монотипії як засобу графрічної виразності у мистецтві. Вісник Харківської державної академії дизайну і мистецтв : Зб. наук. праць. Харків : ХДАДМ, 2016. № 6. C.37-41.

8. Елизавета Кругликова. Международный фестиваль монотипии : веб-сайт. URL http://www.shedevr.com.ua/?author=k/kruglikova (дата звернення : 11.07.2019).

9. Тарханов Михайло Михайлович. Вільна енциклопедія Вікіпедія : веб-сайт. URL : https://uk.wikipedia.org/wiki/Тарханов_Михайло_Михайлович (дата звернення : 11.07.2019).

\section{References}

1. Leshchinskiy A.A. (2003). Graphic basics. Grodno: GrGU [in Russian].

2. Vovchok G. M. (2013). Educational function of illustration of a children's book. Vidavnichij dim «TM Meganom». Retrieved from: https://int-konf.org/ru/2013/suchasnist-nauka-chas-vzaemodiya-ta-vzaemovpliv-18-20-11-2013r/610-vovchok-g-m-vikhovna-funktsiya-ilyustratsiji-dityachoji-knigi (data zvernennya : 11.07.2019). [in Russian].

3. Aksenov G.P. The evolution of the artistic-figurative expressiveness of graphic design in the process of developing printing tools. Chelovek i nauka : Dissertacii po gumanitarnym naukam Retrieved from : http : //cheloveknauka.com/evolyutsiya-hudozhestvenno-obraznoy-vyrazitelnosti-graficheskogo-dizayna-v-protsesse-razvitiyapoligraficheskih-sredstv\#ixzz5tNR6tE00 (data zvernennya : 11.07.2019). [in Russian].

4. Miroshina M.Yu. (2017). Linocut: its types in printed graphics. Molodoy issledovatel' Dona - Young researcher of Don, 3, 141-143 [in Russian]. Russian].

5. Favorskiy V.A. (1986). About art, about the book, about engraving. Moscow: Izdatel'stvo "Kniga» [in

6. Monotype. Graphics. Sait Estetyka u suchasnomu sviti - site Aesthetics in the modern world. Retrieved from http://estetica.etica.in.ua/grafika-yak-vid-mistetstva/ [in Ukrainian].

7. Khramova-Baranova O.L., \& Kukol S.le. (2016). The formation and development of monotype as a means of graphic expression in art. Visnyk Kharkivskoi derzhavnoi akademii dyzainu i mystetstv - Bulletin of the Kharkov State Academy of Design and Arts, 6, 37-41 [in Ukrainian]. 
8. Elizaveta Kruglikova. (2019). International Monotype Festival website. Retrieved from http://www.shedevr.com.ua/?author=k/kruglikova [in Russian].
9. Tarkhanov
Mykhailo
Mykhailovych.
(2019).
Site
Retrieved from

\begin{abstract}
Art
\end{abstract}
investment. https://artinvestment.ru/auctions/1006/biography.html [in Russian].

Стаття надійшла до редакції 03.12.2019 p. Прийнято до публікації 26.12.2019 p.

UDC 738.1:738.3(477)"19"

\author{
Shkolna Olga \\ the doctor of Art criticism, the Professor, \\ the Professor of the Boris Grinchenko Kyiv University \\ ORCID 0000-0002-7245-6010 \\ dushaorchidei@ukr.net
}

\title{
PRODUCTION OF HIGH FAIENCE AT THE PACYKYVSKA FAIENCE FACTORY DURING 1912-1939
}

The purpose of the article. The goal is to outline the main creative achievements of the Patsykyvska faience factory. The methodology consists of the totality of the application of the historical-chronological approach, historicalcultural, axiological and art history methods, which allow you to review previously known information regarding the mentioned production. The scientific novelty consists in the addition and refinement of information regarding the activities of the outlined enterprise and the addition of newly revealed data regarding the owners of the Patsykyvska faience factory. Conclusions. Based on the latest information regarding the formation, development, and activities of the Patsykyvska faience factory, it was possible to verify previously known information on the start of production, which, judging by archival sources, has been operating since 1912. Local history studies of the village of Pidlissya, which, according to the new administrative-territorial division, covers Patsykyv's former territories in the vast modern Ivano-Frankivsk region made it possible to supplement the information on the stages of reconstruction and modernization of the enterprise, previously unknown to the general public related to the wartime of 1914-1918. The identification of the latest archival data, photographs, and sights from various state and private collections of Ukraine and Poland over the past years made it possible to clarify the names of the production of different periods, which was originally called the Erst Galician Factory of Faience and Terracotta in Patsykyv near Stanislavov, and in the interwar period - Polish factory of faience «Patsykyv» near Stanislaviv.

Key words: Patsykyvska faience factory, Ukraine, XX century, owners, enterprise infrastructure.

\begin{abstract}
Школьна Ольга Володимирівна, доктор мистецтвознавства, профресор Київського університету імені Бориса Грінченка

Продукування високого фаянсу на Пациківській фаянсовій фабриці впродовж 1912-1939 рр.

Мета - розглянути особливості фабрикації скульптури і посудних виробів на Пациківській фаянсовій фрабриці впродовж 1912-1939/1941 рр. Методологія дослідження складається з сукупності застосування історико-хронологічного підходу, історико-культурного, аксіологічного та мистецтвознавчого методів, які дозволяють переглянути раніше відому інформацію щодо згаданого виробництва. Наукова новизна полягає у доповненні й уточненні відомостей щодо діяльності Пациківської фаянсової фабрики у період з 1912 по 1939/1941рр. Висновки. Виходячи з останніх відомостей відносно становлення, розвитку і функціонування Пациківської фраянсової фабрики, вдалося здійснити верифікацію раніше відомої інформації щодо початку діяльності виробництва, що, судячи з архівних джерел, діяла з 1912 р. Краєзнавчі дослідження села Підлісся, яке за новим адміністративнотериторіальним поділом охоплює колишні території Пацикова на теренах сучасної Івано-Франківщини, дозволили доповнити відомості про етапи реконструкції та модернізації підприємства, раніше невідомі широкому загалу, пов'язані із воєнним часом 1914-1918 рр. Виявлення новітніх архівних даних, світлин і пам'яток з різних державних і приватних збірок України та Польщі впродовж останніх років, уможливили уточнення назв виробництва різних періодів, що початково іменувалося Перша Галицька фабрика фаянсу і теракоти в Пацикові біля Станіславова, а у міжвоєнний час - Польська фрабрика фаянсу «Пациків» біля Станіславова.
\end{abstract}

Ключові слова: Пациківська фраянсова фрабрика, Україна, XX століття, власники, інфраструктура підприємства.

Школьная Ольга Владимировна, доктор искусствоведения, профрессор Киевского университета имени Бориса Гринченко

Продуцирование высокого фаянса на Пациковской фаянсовой фабрике в течение 1912-1939 гг.

Цель - очертить основные творческие достижения Пациковской фаянсовой фабрики. Методология исследования состоит из совокупности применения историко-хронологического подхода, историко-культурного, аксиологического и искусствоведческого методов, которые позволяют пересмотреть ранее известную информацию относительно упомянутого производства. Научная новизна заключается в дополнении и уточнении сведений касательно функционирования очерченного предприятия и прибавления нововыявленных данных относительно владельцев Пациковской фраянсовой фабрики. Выводы. Исходя из последних сведений относительно становления, развития и деятельности Пациковской фаянсовой фабрики, удалось осуществить верификацию ранее известной информации относительно начала деятельности производства, что, судя по архивным источни-

(C) Shkolna O., 2020 